緑化協定および建築協定両制度締結による戸建住宅地接道部緑化 の効果に関する研究

\title{
A STUDY ON THE EFFECT OF GREENING ON ROAD SIDE IN DETATCHED HOUSING AREA BY THE PLANTING AGREEMENT AND THE BUILDING AGREEMENT
}

\author{
山口 紘*, 坂.本磐雄**, 田中正美***, 前田 修**** \\ Hiroshi YAMAGUCHI, Iwao SAKAMOTO, Masayoshi TANAKA and Osamu MAEDA
}

\begin{abstract}
The double standards by the planting agreement based on the preservation law of urban green and the building agreement based on the building standard law contributes mainly to greening of detatched housing area. The most important item influencing effect of planting among items of the agreements is the structure of hedge or wall.

The correlation between effect of planting on hedge or wall of roadside in housing site and application of the structure of hedge or wall of the items was made clear through the research on the actual condition (79 detatched housing areas of the double standards). Also, the correlations on effect of greening between the structure of hedge or wall and another 8 factors (set back distance, lot scale, developer, conclusion method, topography, area scale, sanction age, regional differences) were made clear.
\end{abstract}

Keywords:townscape, detatched housing area, the planting agreement, the building agreement, greening of roadside, application,

景観, 戸建住宅地, 緑化協定, 建築協定, 接道部緑化, 運用

1.はじめに

本研究は、戸建住宅地における統一感のある町並景観 の視点より、宅地の接道部緑化を考えるものである。

本研究グループは、種々の自治体施策の中から戸建住 宅地を主体に区域単位の接道部緑化が期待される都市緑 地保全法に基づく緑化協定、および建築基準法に基づく 建築協定に着目し、1988年上り関東以西における戸建住 宅地両協定区域の実態調查を行なってきた。調查を進め る中で、両協定を共に締結している区域（以下文中では 二重協定とする）が少なからずあり、そこでは接道部緑 化の状況が、単独の協定区域よりかなりよい傾向が自受 けられ、極めて注目された。いそこで、一般的傾向を把 握するため、出来るだけ全国的に調查を行なった。

緑化協定および建築協定制度を対象とした既往研究で は、協定の接道部緑化効果を指摘した論文はかなり見受 けられるが、接道部緑化の実態調査を行なって、その結 果の差異を分析し効果增進に言及したものはない。また、
二重協定の実施状況およびその緑化効果を指摘し、効果 の分析を行なった研究は皆無である。かかる状況にあっ て本研究グループは、緑化協定と建築協定制度による接 道部緑化の効果に関した論文 2). 31 を発表してきた。 この中では、緑化協定、建築協定各々の接道部緑化の効 果を、一般住宅地との比較を通じて確認し、さらに協定 区域間の効果の差異の主因として、緑化協定では、協定 書中の接道部垣 : 栅の構造、区域開発企業の規模、協定 締結要件を、また建築協定では、協定書中の接道部垣・ 塀の構造、道路側外壁後退距離、区域開発企業の規模に あることを指摘した。そして全国の実施自治体へのアン ケート調查を通じて運用の実態を把握し、実態調査区域 だけでなく協定区域一般の問題として協定の運用や行政 指導などに関する提言を行なった。

以上のような経緯をふまえて、本報では二重協定につ いて、

(1)全国の実施状況を把握する。

* 九州東海大学工学部建築学科 助教授·工修 Assoc. prof., Dept. of Architecture, Faculty of Engineering, Kyusyu

** 八戸工業大学建築工学科 教授 $\cdot$ 工博

**** 東和大学工学部建設工学科 教授 Tokai Univ., M. Eng.

Prof., Dept. of Architectural Engineering, Hachinohe Institute of Technology, Dr. Eng.

Prof., Dept.
Towa Univ.

*****東和大学工学部建設工学科 講師

Lect., Dept. of Architectural Engineering, Faculty of Engineering, Towa Univ. 
(2)実態調查により、非協定一般住宅地との接道部緑化状 況を比較し、二重協定の効果を確認する。

(3)単独の各協定で明らかにされた接道部緑化効果に最も 影響を及ほす協定書中の垣・塀の構造の指定が、本研究 では両協定によって二重に指定される点を考察の主要課 題に据え、区域間の効果の差異と、指定の内容および方 法の相関を、実態調查の結果より解明する。

(4)垣 ·塀の構造の指定内容による接道部緑化効果は、効 果の差異をもたらすと考えられる他の要因、すなわち建 築協定中の道路側外壁後退距離、敷地規模、事業主体（ 分䛦時の生垣設置有無を含む）。協定の締結要件、住宅 地の地形、区域規模、認可年、地域性などと、どのよう に係わっているかを娭討し、その影響度を明らかにする。

以上を通じて、今後の二重協定締結の際の緑化関連事 項の運用、特に垣・垪の構造の指定内容と方法、および 行政指站や事業者努力などに関して有効な提言を行なう ことを研究目的とする。

なお、接道部緑化効果は、道路から見える緑化量とし て二つの要素から判定する。一つは平面的な緑化設置量 であり、生垣を主とした接道部緑化の有無による区域の 緑化設置率を指標とする。他の一つは道路側から見た立 体的緑化量であり、生垣などの見える量を規制する敷地 面からの道路側ブロック積み段数による区域ブロック段 数率を指標とする。以上の 2 指標によって各区域の緑化 効果を判定し評価を行なう。

\section{2. 調査の方法および結果の評価 \\ 2-1 調查の方法}

実態調查の対象は、区域各戸の接道面における植栽可 能な場所（門迴りおよび駐車スペース以外）の半分以上 を占めるものを当該接道部（極端に狭い場合は除外）の 垣・塀とし、その(1)生垣などの有・無(2)ブロック積みの 有無および住宅敷地面からの段数(3)フェンス・ネットの 有無、などを調査する。なお、緑化設固量はほとんど生 垣であるが、低木が生垣状に植栽されている場合も含め ている。また、接道面の中高木は対象にしていない。

接道面の状況は、大きく分けて(1)生垣だけ(2)生垣の外 側にブロック積み(3)生垣の外側にフェンスまたはネット (4)生垣がなくブロック、フェンス、ネットだけ(5)何もな し、の結果となる。なお、生垣前面のフェンス・ネット は、道路側から見た効果が実質的には生垣だけと差異が ないため、分析では、生垣だけと同様に取り扱う。

\section{$2-2$ 調查結果の評価}

調査結果より、各区域毎に緑化設置率（緑化率）=緑 化設置接道面数/区域全体の接道面数、および各接道面 のブロック積み段数を $0 \sim 3$ 段、4〜 5 段、6 段以上に 3 区分した各割合を求める。段数区分の基準は、協定書
中の垣・塀の構造指定にブロックなどは $0.5 \sim 0.6 \mathrm{~m}$ 以下、 あるいは1.0 1.2m以下、という内容がしばしば見受けら れることと、実態調查での印象を加味して、ブロック寸 法（標準高 $20 \mathrm{~cm} ）$ より 3 段、6段を目安にした。なお、 ブロック塀の中空きタイプは、中空きの広さにより全体 高より 1 〜 段減じて取扱った。またブロック段数には、 フェンス等の基礎部分として、あるいは生垣の場合でも 土どめとしてある程度積まれる場合が多いが、これも含 める。

区域の評価は、道路から見える緑化量を基隼とする。 従って区域の緑化効果は、各接道部に生垣などの設置が 多い場合と、その前面道路側ブロック段数の低い割合が 多い場合が高い評価を得る。そこで、評価基準として緑 化率と 3 段以下率（区域におけるブロック積み 0 〜 3 段 の割合）を指標にとり、各々の指標を、図一 1 に示すよ うに $90 \%$ 以上、80〜90\%、70〜80\%、60〜70\%、50〜60 $\% 、 50 \%$ 末満の 6 区分を基本にクロスさせ、かつ、各一 方の指標が高い場合は上位修正して、それぞれ $A^{+} 、 A 、$ $B 、 C 、 D 、 E の 6$ 段階評価を行なった。実態調査の印 象でも、A評価以上の区域は、接道部の緑化状況の良さ が実感できた。

\section{3. 二重協定の概要}

建設省資料"1）（1990年 3 月末迄）によると、緑化協 定は106自治体748区域、建築協定は358自治体2200区域、 締結されている。緑化協定の施行は、1974年 2 月からで あるが、二重協定区域は、1975年に 2 自治体 5 区域で実 施され、1989年迄に29都・府・県、56区・市・町（1区 ·43市・12町）、184区域が確認された。これは緑化協 定区域の $25 \%$ 、建築協定区域の $8 \%$ たあたる。その締結 の推移と、分布状況を図一 2 、図一 3 に示す。締結状況 は自治体数、区域数とも80年代より増加し、その後一定 した傾向にある。分布状況は80年代前半に関西以東で多 くなり、現在は北海道以外ほぼ全国的に分布している。

協定区域の用途および内容は、商・工用地 2 区域、既 成住宅地 5 区域、集合住宅地（戸建地との混合含む）14 区域あるが、他は全て開発戸建住宅地でありその主体と いえる。

諗可年（90年 4 月以降認可の 12 区域の調査地含む 196 区域）は、25区域で両協定間に数年のづれはあるが、大 半は同一年度中であり、二重協定は同時期に締結される 傾向にある。なお認可年が違う場合の22区域中（緑化協 定施行以降）、緑化協定が先行している場合が17区域、 建築協定先行が 5 区域である。先行の年数 3 年以上の場 合、緑化協定8/17区域、建築協定1/5区域である。

区域の面積（196区域）は最大65.38ha、最小0.17haで ある。規模内訳は 3 ha未満88区域 $(45 \%) 、 3 \sim 10$ ha77 


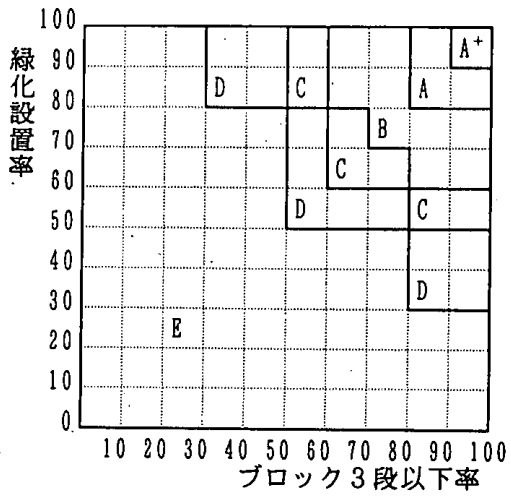

図一 1 評価区分

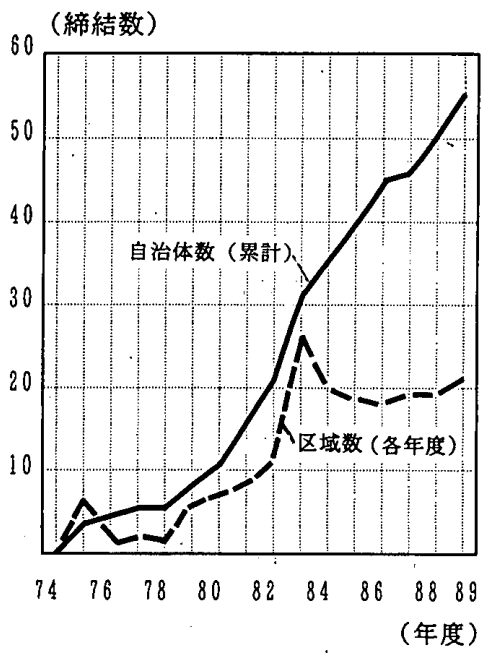

因一２二重協定締結の推移

\section{表一 1 調査区域の概要と緑化評価}

\begin{tabular}{|c|c|c|c|c|c|c|c|c|c|c|c|c|c|c|c|c|c|}
\hline \multirow{3}{*}{$\begin{array}{l}\text { 臬 } \\
\text { 名 } \\
\text { 多 }\end{array}$} & \multirow{3}{*}{ 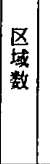 } & \multirow{3}{*}{ 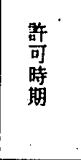 } & \multirow{3}{*}{ 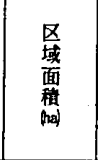 } & \multirow{3}{*}{ 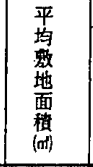 } & \multirow{3}{*}{$\begin{array}{l}\text { 噟 } \\
\text { 突 }\end{array}$} & \multirow{3}{*}{ 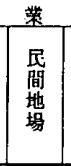 } & \multirow{3}{*}{ 主 } & \multirow{3}{*}{$\begin{array}{c}\text { 体 } \\
\text { 公 } \\
\text { 基 } \\
\text { 場 }\end{array}$} & \multicolumn{4}{|c|}{ 瑺㚘要 件 } & & \multicolumn{4}{|c|}{ 緑 化 㫠 俅 } \\
\hline & & & & & & & & & 禹 & 雱 & 建 & & & \multicolumn{2}{|c|}{$\begin{array}{l}\text { Lu } \\
\text { 劦定内容 }\end{array}$} & \multicolumn{2}{|c|}{$\begin{array}{l}\text { 望の他の } \\
\text { 定内欲 }\end{array}$} \\
\hline & & & & & & & & & & & & & & $x, A$ & $B-E$ & $R, A$ & $B \sim E$ \\
\hline 福威市 & 7 & $82 \dot{\prime}^{\prime} 91$ & $0.7 \sim 27.3$ & $180 \sim 285$ & $5(5)$ & $1(0)$ & & $1(1)$ & 2 & 4 & 1 & & 1388 & 5 & 0 & 1 & 1 \\
\hline 北儿州市 & 4 & '89*' 90 & $2.7 \sim 4.0$ & $210 \sim 240$ & & $4(3)$ & & & 2 & 2 & & & 310 & 2 & 0 & 1 & 1 \\
\hline 新容町(揊岡) & 3 & ' $822^{\prime} 90$ & $2.8 \div 12.3$ & $200 \sim 325$ & $3(3)$ & & & & & 2 & & 1 & 573 & 3 & 0 & 0 & 0 \\
\hline 遗贺町(福融) & 1 & ' 85 & 8.5 & 230 & $1(1)$ & & & & & 1 & & & 283 & 1 & 0 & 0 & 0 \\
\hline 悲本市 & 8 & ' $79 \div 88$ & $0.9 \sim 11.5$ & $210 \sim 400$ & $2(2)$ & $4(1)$ & & $2(2)$ & 2 & 6 & & & 1087 & 2 & 2 & 3 & 1 \\
\hline 别㤢市 & 1 & 86 & 8.3 & 210 & & $1(0)$ & & & & & 1 & & 34 & 0 & 0 & 0 & 1 \\
\hline 泝世保市 & 1 & ' 84 & 4.9 & 220 & 1(1) & & & & & 1 & & & 250 & 1 & 0 & 0 & 0 \\
\hline 広島市 & 3 & ' $81 \div ' 83$ & $0.8 \sim 1.3$ & $149-213$ & & & & 3(2) & & & & 3 & 329 & 0 & 0 & 2 & 1 \\
\hline 计帕 & 2 & ' $84 \sim^{\prime} 85$ & $0.2 \sim 3.2$ & 186 & & & $2(2)$ & & & 2 & & & 340 & 0 & 0 & 2 & 0 \\
\hline 福山市 & 2 & 87 & $0.8-27.4$ & $206-215$ & I(1) & & & $1(0)$ & 1 & 1 & & & 311 & 0 & 0 & 1 & 1 \\
\hline 川西市 & 1 & ' 83 & 3.1 & 200 & $1(1)$ & & & & & 1 & & & 78 & 1 & 0 & 0 & 0 \\
\hline 吹田市 & 1 & 83 & 1.5 & 133 & $1(0)$ & & & & & 1 & & & 40 & 0 & 1 & 0 & 0 \\
\hline 字治市 & 5 & '81*90 & $0.3 \times 11.6$ & 140-180 & $3(2)$ & $2(0)$ & & & 1 & 2 & 2 & & 851 & 0 & 0 & 2 & 3 \\
\hline 酒松市 & 7 & '75:' 87 & $1.5 \sim 6.8$ & $170 \sim 225$ & 1(1) & $4(3)$ & 1(1) & $1(1)$ & 4 & 2 & 1 & & 796 & 6 & 0 & 0 & 1 \\
\hline 菚野节 & 1 & 83 & 4.6 & 280 & & & & $1(0)$ & & & & 1 & 157 & 0 & 0 & 0 & 1 \\
\hline 干积市 & 8 & $790^{\circ} 91$ & 1.1 122.9 & $140 \sim 165$ & $6(6)$ & & & $2(1)$ & 3 & & 5 & & 1079 & 3 & 0 & 4 & 1 \\
\hline 小川町（埼玉 & 3 & $800^{\circ} 87$ & 2.1225.9 & 190 195 & 3(3) & & & & 2 & & 1 & & 1147 & 2 & 0 & 1 & 0 \\
\hline 幏山町(埼玉) & 3 & $82 \div 88$ & $1.7 \sim 3.5$ & 190 & 3(3) & & & & & 2 & & 1 & 411 & 0 & 0 & 3 & 0 \\
\hline 所祄市 & 3 & $\begin{array}{l}{ }^{\prime} 80^{\circ} 84 \\
\end{array}$ & 3. 3 37.8 & $180-200$ & $3(3)$ & & & & 3 & & & & 362 & 0 & 0 & 3 & 0 \\
\hline 前淿市 & 9 & ' 75^' 90 & $1.1-15.0$ & $160 \sim 350$ & & $2(0)$ & & $7(2)$ & 2 & 7 & & & 2362 & 0 & 0 & 2 & 7 \\
\hline いわき市 & 1 & 82 & 17.3 & 300 & & & 1(1) & & & 1 & & & 63 & 0 & 0 & 1 & 0 \\
\hline 秋畩市 & 5 & '75ं' 89 & $1.2 \sim 5.3$ & 202 300 & & $4(0)$ & $1(1)$ & & 1 & 3 & 1 & & 338 & 1 & 0 & 0 & 4 \\
\hline it & 79 & '75-'91| & $0.2 \sim 37.8$ & $140-400$ & \begin{tabular}{|c|}
34 \\
$332)$ \\
\end{tabular} & $\begin{array}{c}22 \\
(7) \\
\end{array}$ & $\begin{array}{c}5 \\
(5) \\
\end{array}$ & \begin{tabular}{|c}
18 \\
$(9)$
\end{tabular} & 23 & 38 & 12 & 6 & 12589 & 27 & 3 & 26 & 23 \\
\hline
\end{tabular}

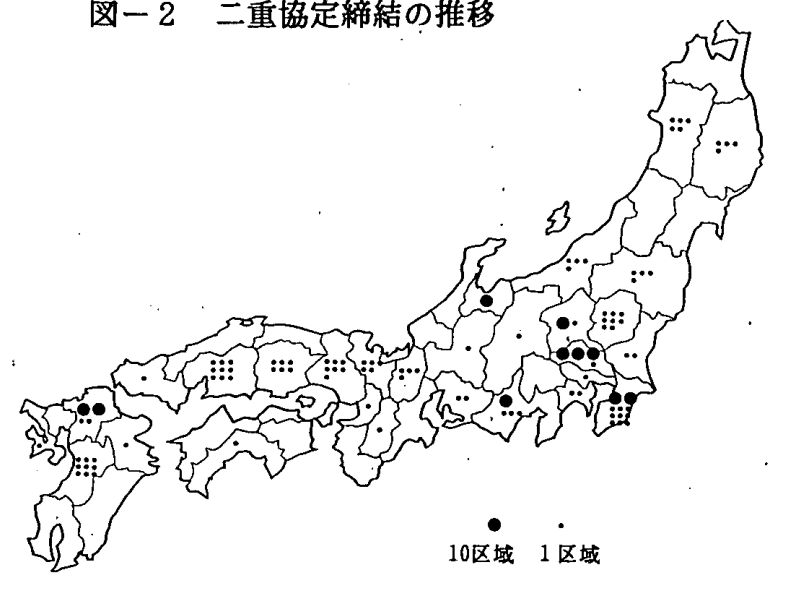

图-3 二重協定区域の分布

区域（39\%）、10ha以上31区域（16\%）となっている。 なお、大団地は開発段階により数次に亘って締結される 場合があり、区域数、区域面積に影響する。また、区域 の指定面積は、119区域は両協定同一である。他の大半 も、指定面積の算定の仕方（例えば、建築協定では敷地 部分のみ）などによるとみられる多少の相違はあるが、 ほほ同一の範囲とみなされる。ただし、緑化協定の10区 域、建築協定の 5 区域では一方よりかなり広く、同じ団 地内での一部が二重協定区域である場合もみられる。

\section{4.二重協定区域の接道部緑化効果}

\section{4-1 実態調查地の概要}

（1）一般住宅地：1975年以降開発の福岡市近郊 3 市、 1 町50地区の戸建住宅地（1664接道面）と熊本市郊外部. 戸建住宅地の 5 団地（1092接道面）の調査結果を図一 4 に示した。

（2）二重協定区域：2 府13県、18市4 町の79区域、 接道面数12589面の調査を行なった。調査した自治体数、 区域は、全締結件数（.90.3月迄）の各約 4 割で、ほ ほ全国的に分布している。また、種々の分析項目につい ても检討の結果、ほほ全国的傾向を示し得ると考えられ る。ただし、事業主体（区分の定義は $5-3$ に示す）の 公共地場は一部自治体に偏りがあり、公共中央は事例が 少ない。区域の概要および調查結果を表一 1 に示す。な お、広い区域では、同様の傾向とみて全体を調查してい ないところもある。また、調査後、建築協定の一部に地 区計画に移行した区域、有効期間が終了した区域もある。 更新した区域は、当初の認可年を示寸。全区域、開発住 宅地であるが、開発形態（建売分培、宅地分譲など）は 


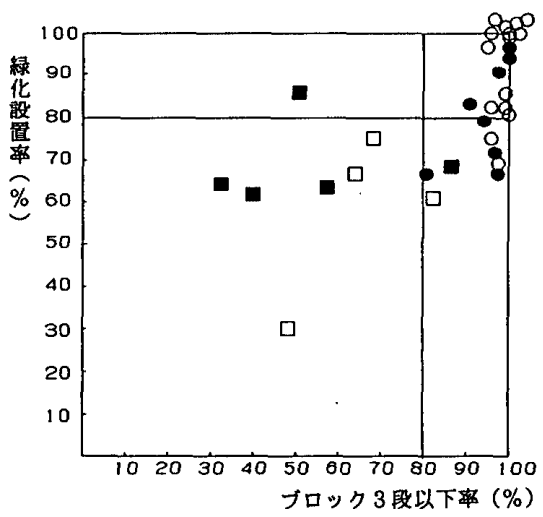

表一 2 協定内容組合せと緑化評価

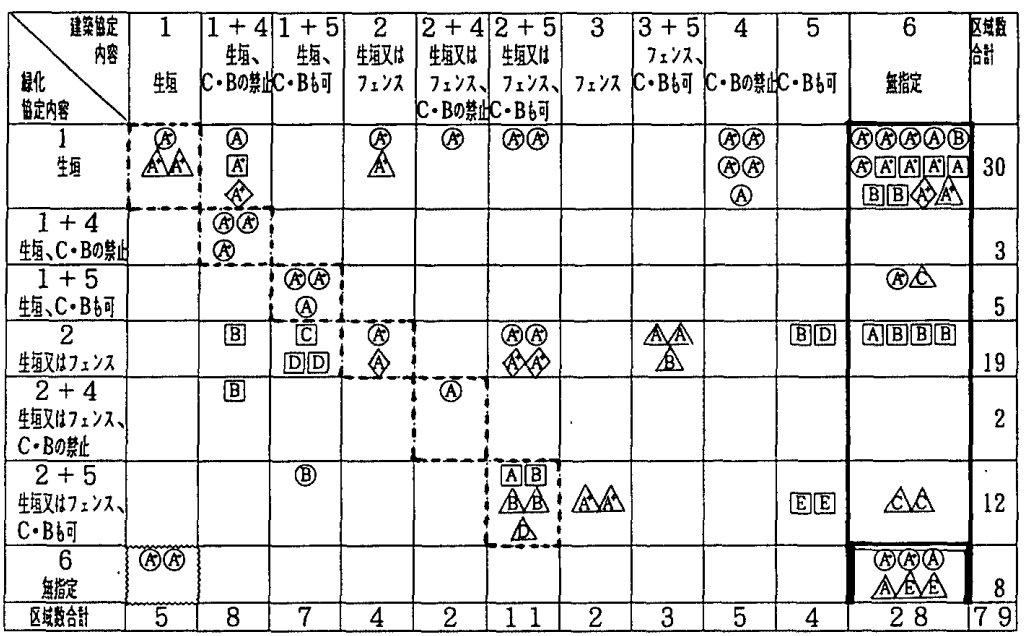

口福同连一般住宅地

能本市二重協定区域

能本市一般住宅地

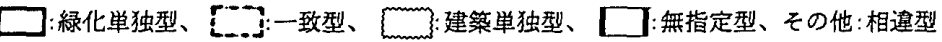

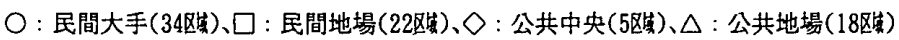

調查不十分でデータに示していない。

図ー4に示した福岡県の二重協定区域は、2市 2 町、15 区域2554接道面。熊本市は 8 区域1087接道面。

（3）調査期間：1988年～1993年。

4-2 二重協定の接道面緑化効果

二重協定調查全区域の結果は、垣・摒の構造指定別で 表一 2 に示した。評価の内訳は、 $\mathrm{A}^{+}: 41$ 区域、A : 12 区域、B：14区域、C：14区域、D：4区域、E：4区 域であり、A以上は、53/79区域 $(67 \%)$ になる。

二重協定区域と非協定一般住宅地の接道面緑化状況を、 同一地域における比較として、福岡県と熊本市の場合を 図一 4 に示した。評価 A 以上は、二重協定区域の場合、 福岡県 $87 \%$ 、熊本市 $63 \%$ であるが、一般住宅地では両地 域共皆無である。これより、二重協定は非協定一般住宅 地より各指標が高く、明らかに効果が認められる。

\section{5．垣・塀の構造の指定内容および指定方法と接道部 緑化効果}

5-1 協定書中の垣・塀の構造の指定内容

協定書の指定内容を要約して、分類すると表一 3 のよ うに示される。表一2などで示した指定内容の数字は、 この表一 3 における分類番号で、以下便宜的に文中では [1：生垣〕は〔1〕、〔2+4:生垣またはフェンス、 C ・ Bの禁止〕は[2+4]…と表わす場合がある。 指定内容の各協定による組合せは、具体的には表一 2 の 通り調查区域全部で26夕イプになる。各々の協定による 指定を、優位をつけず対応する立場から巾広く解釈すれ は、表ー 4 のように指定内容を 6 種類の系列に大別でき ると考えられる。これに従えは、、26のタイプは図ー5に 示す通りとなる。この 6 分類のうち、事例の多い 4 分類 についての実態調查の結果をみたのが図一6〜困ー9で
表一 3 垣・塀の搼造の指定内容分類

\begin{tabular}{|c|c|}
\hline 1 & 生垣、原則生垣、（生垣とフェンス型用も含む） \\
\hline 2 & 生坦又はフェンス （原則生坦だがフェンスも可、含む） \\
\hline 3 & フェンス （ネット、開放的な栅も含む） \\
\hline 4 & 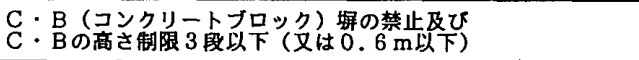 \\
\hline 5 & 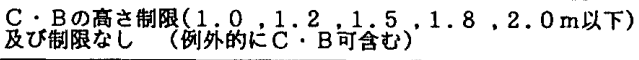 \\
\hline 6 & 無指定 \\
\hline
\end{tabular}

表 -4 垣・塀の構造の指定内容系統別分類

\begin{tabular}{|c|c|c|c|}
\hline 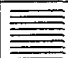 & 1 と 4 の系 & 14 区域 & 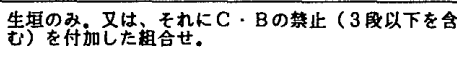 \\
\hline & 1 と6の系 & 16 区城 & 生埯と整指定の粗合せ。 \\
\hline 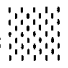 & 2 と4の禾 & 12 区域 & 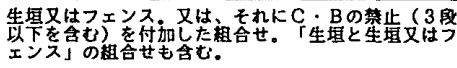 \\
\hline 無事 & 2 と 5 の系 & 26 区域 & 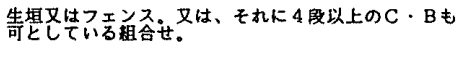 \\
\hline$m$ & 1と5の齐 & 5 区域 & 生坦と 4段以上のC・Bも可としている相合せ。 \\
\hline & 6 と6の系 & 6 区域 & 两協定とも僛指定. \\
\hline
\end{tabular}

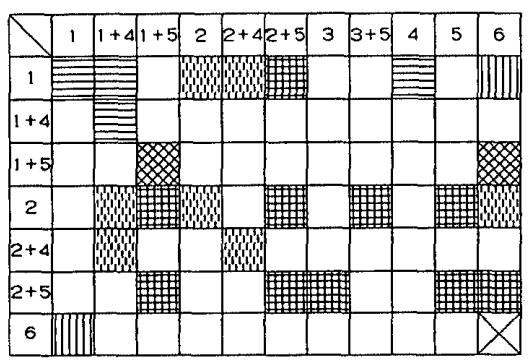

1. 生塭 2. 生坦又はフェンス 3.フェンス

4. CBの慗止及ひ高さ制限三段以下 (0.6 m以下)

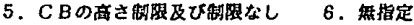

\section{図一 5 協定内容組合せの系統別分類}


ある。各分類における評価 $\mathrm{A}$ 以上の割合をみると、〔 と 4 の系〕は $14 / 14$ 区域 $(100 \%) 、 〔 1$ と6の系〕は 13 $/ 16$ 区域 $(81 \%) 、 〔 2$ と 4 の系〕は7/12区域 (58\%)、

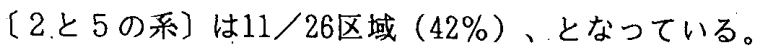
なお、〔 1 と 5 の系〕と〔6と 6 の系〕は、今回の調査 では比較的よい結果であるが、事例が少なく、また 1 自 治体のみの例外的タイプなどであり、一般的傾向は分ら ない。この結果と指定内容から、〔 1 と 4 の系〕、〔 と6்系りを以下の分析では〔よい協定内容（よい内容 の垣・塀の構造の組合せ指定）〕とする。

5-2 緑化協定と建築協定における指定状況

各協定における指定状況を表一2 に示す。建築協定で は、〔無指定〕が35\%と非常に多く、他は様々で目立っ た傾向はない。一方緑化協定では、【生垣〕 $38 \%$ 、〔生 垣又はフェンス〕 $24 \%$ 、〔生垣又はフェンス、C・Bも 可了 $15 \%$ となっており、この3指定が約 8 割を占める。 無指定は例外的に千葉市の 7 例である。以上の傾向から、 緑化協定の3 指定が主導的な役割をはたしているといえ る。そこで、これら 3 指定と建築協定内容の組合せ、お よび各組合せにおける評価の一般的傾向をみる(表一2)。

（1）緑化で〔1：生垣（1+4も含む）〕を指定した

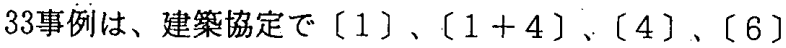
と組合わせるケースが、28/33区域 $(85 \%)$ あり、〔よ い協定内容〕となる傾向が強く、評価 $\mathrm{A}$ 以上は $30 / 33$ 区 域 (91\%)，で好結果になりやすい。なお、この場合〔6 . 無指定了と組合せる割合が14/33区域 $(42 \%)$ と高く、 評価 A以上は $11 / 14$ 区域（79\%）と結果もかなり良い。 この組合せは事例中最も多く、二重協定の代表的タイプ といえる。これは接道面緑化を緑化協定に委わた結果と 考えられる（事業者ヒヤリングなど）。

（2）緑化で〔2：生垣又はフェンス、( $2+4$ 含む)] は、建築協定で〔 5 : C・Bも可〕を含んだ内容と組み 合わさるケースが、12/21区域 (57\%) あり、〔2 と 5 の系了になりやすく、評価A以上は10/21区域（47\%） で結果が落ちる。

（3）緑化で〔·生垣又はフェンス、C・Bも可〕は、建 築協定の[C：Bも可〕と組合さるケースが8/12区域
（67\%）あり、評価 A以上は $3 / 12$ 区域（25\%）と最も よくない。

（4）以上より、緑化協定での指定が主導的役割を果す と考えられる。その場合、〔生垣〕の指定は建築協定と の組合せでよい協定内容になる可能性が高く、結果も極 めてよい。一方、〔生垣又はフェンス〕および〔生垣又 はフェンス、C・Bも可〕の指定ではよい結果が期待で きない。

5-3 緑化協定と建築協定による指定の方法と内容 各々の協定で指定された内容の組合せは、表一 2 に示 した $5 つ の$ 指定方法に分類される。. 5 つの指定方法を本 論では、緑化協定のみの内容指定で建築協定は無指定で ある場合を〔緑化協定単独型〕、緑化・建築両協定共、 同じ内容を一致して指定する場合を〔両協定一致型〕、 緑化・建築両協定が、各相違する内容を指定する場合を 〔両協定相違型〕、建築協定のみの内容指定で緑化協定 は無指定である場合を〔建築協定単独型〕、緑化・建築 両協定共、無指定の場合を〔無指定型〕とした。また、 事業主体（業務代行、委託含む）については、民間が主 として東京、大阪に本社をおく全国的企業を民間大手、 地方中心の企業を民間地場、公共的機関で全国的に事業 を行なうもの（住·都公団、地・振公団、勤住協など） を公共中央、地方に限定されるもの（自治体の住宅供給 公社など、および第三セクターも含む）:公共地場とす る。以下、各指定方法の内容と評価より有効な指定方法 と内容を検討する。

（1）緑化協定単独型は、該当22区域（民間大手 7、民 間地場 10、公共中央 1 、公共地場 4）あり、民間地場に 多く、全体的評価は A 以上 $13 / 22$ 区域 $(59 \%)$ 、全体的 状況は図ー10に示す。評価 A 以上の内訳をみると〔1:生 垣了がほとんどを占める（11/13区域）。したがって、 緑化協定単独の場合においても〔1:生垣〕の指定は緑化 上有効である。一方，〔2]、[2+5]、[1+5] の指定は〔2〕で緑化率、〔5〕で三段以下率の低下の 可能性があり（図一10）指定上問題がある。以上より、 建築協定では無指定が多い状況を勘案すると、緑化協定 での〔生垣〕指定が益々必要となる。特に、この型に多

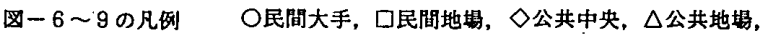

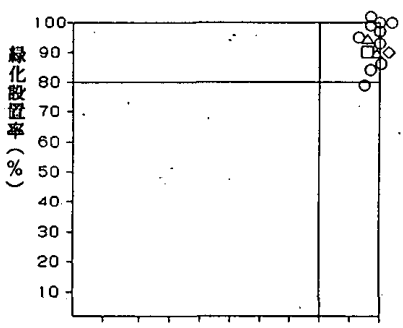

圀 6

102030405060708090100 垣・塀の構造の指定内容 [1 と4の系]の緑化状況

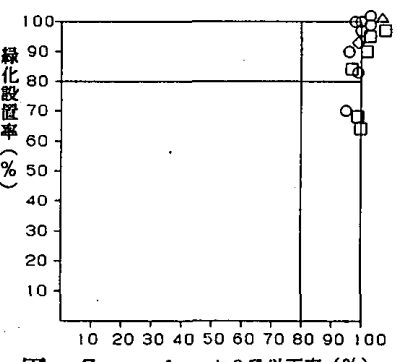

因-7 垣・城の㩐造の指定内容 〔1と6の系〕の緑化状況

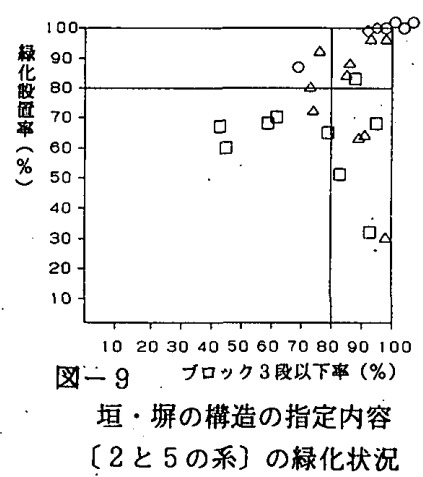


い民間地場の場合も〔1：生垣〕の指定では、評価 A 以 上4/6区域（他の指定 $1 / 4$ 区域）であり、その指定が望 まれる。

（2）両協定一致型は、該当17区域（民間大手 8、民間 地場 3 、公共中央 1 、公共地場 5 ）あり、民間大手と公 共地場に多く、全体的評価では A 上上 $13 / 17$ 区域（76\% )である。しかし〔よい協定内容〕は、6/17区域と少な く、事業主体の分袞時における計画的生垣整供など他の 要因によると考えられる（6-3（1）で後述）。この 方法では、図ー11に示すように、緑化設置率の低下がみ られる[2+5]の指定をさけて、〔1]、〔 $1+4]$ の〔よい協定内容〕による指定を行なえば極めてよい評 洒（評価 $\mathrm{A}$ 以上6/6区域で100\%）が期待できる。しか し、この指定は少ない現状であり当事者間の努力が要請 される。特に、公共地場の場合 5 区域の事例では〔1〕 の指定 2 区域、〔 $2+5]$ の指定 3 区域と対応の差が見 受けられるので努力が望まれる。

（3）両協定相違型は、該当32区域（民間大手14、民間 地場 9 、公共中央 3 、公共地場 6 ）あり、最も多く、か つどの事業主体でも行なわれやすい一般的な方法である。 全体的な評価は A 以上 $18 / 32$ 区域 $(56 \%)$ で比較的よく ない。全体的状況は図一12に示す。〔よい協定内容〕の 区域は $8 / 32$ 区域（25\%) と少なく、指定〔5：C・B も可了の内容を含んだ19区域があるなど、この方法は、 よい協定内容以外の組合せが多い。そして結果も悪い指 定内容の方に影響される傾向がある（図ー12）。これは、 相違型の現状が各指定の際、調整なく行なわれた結果で はと推察され、区域数と悪い協定内容が多い点、二重協 定としての問題であると考えられる。従って当事者間の 協議が何より望まれる。この相違型でも、緑化で〔1〕、 建築で〔 $1+4 〕 、 〔 4 〕$ を指定すれば評価 $\mathrm{A}$ 以上 $8 / 8$ 区域 $(100 \%)$ と著しくよい結果を得ている。

（4）無指定型, 建築協定単独型は、該当 8 区域中 7 区 域は千葉市であり一般的なタイプではないと思われる。 しかし、千葉市の場合における建築協定単独型は、建築 協定で〔生垣〕の指定を行ない、緑化協定では垣・塀の
構造を〔無指定〕として、中高木の指定に重点をおく方 法は注目される。

（5）以上の検討結果より

（イ〕緑化協定単独型では〔生垣〕の指定でかなり効果 がある。

（ロ）両協定一致型では〔生垣〕、〔生垣、C・Bの禁 止〕を一致して指定すると著しく効果がある。

（八）両協定相違型では、緑化で〔生垣〕、建築で〔生 垣、C・Bの禁止〕、〔C・Bの禁止〕を指定すると著 しく効果がある。

（二）以上より、緑化協定での〔生垣〕指定は、どの方 法（型）でも必要であり、かつ建築協定の内容をよいも のに主導する可能性が極めて高く重要である。

\section{6. 接道部緑化効果における垣・塀の構造の指定内容 と、その他の要因との関係 \\ 6-1 建築協定書中の外壁後退距離と接道部緑化効 果}

建築協定の協定書において、調查区域の 8 割が指定し ており、その内訳を表一 5 に示す。指定距離による評価 は、無指定から $1.0 \mathrm{~m}$ 以上までは差がないが、1.5m以上に おいてはよい傾向がうかがわれる。しかし、よい協定内 容の場合には指定距離のいかんにかかわらず評価 $\mathrm{A}$ 以上 の割合が高いが、その他の協定内容では $2 \mathrm{~m}$ 以上以外はど の指定距離でも評価 $\mathrm{A}$ 以上の割合が低い。このことより、 緑化には距離指定より協定内容が影響度が高いことを示 しているといえる。

ただし、指定距離 $1.5 \mathrm{~m}$ 以上は、よい協定内容を指定す る割合が15/21区域 (71\%) で1.0m末満の5/21区域（ $24 \%$ ）、1.0～1.5mの10/37区域（27\%）と比べてかなり 高く、よい協定を指定する可能性のあることが注目され る。なお、今回の調查では、 $1.5 \mathrm{~m}$ 以上の指定は、全て數 地面積 $180 \mathrm{~m}^{2}$ 以上で行なわれている。180 $\mathrm{m}^{2}$ 以上の割合は 事業主体別では、民間地場が20／22区域（91\%）で民間 大手 $(74 \%)$ や公共地場（78\%）よりかなり高い。そし

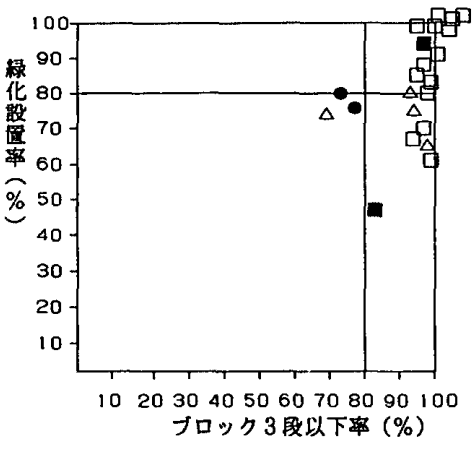

図-10 垣・垪の梏造の指定方法 〔緑化協定単独型〕の緑化状況

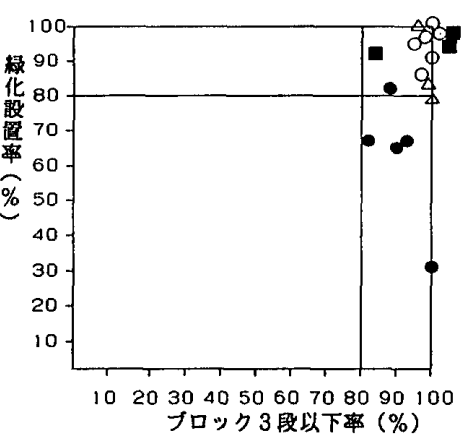

图-11垣・塀の粠造の指定方法 〔両協定一致型〕の緑化状況

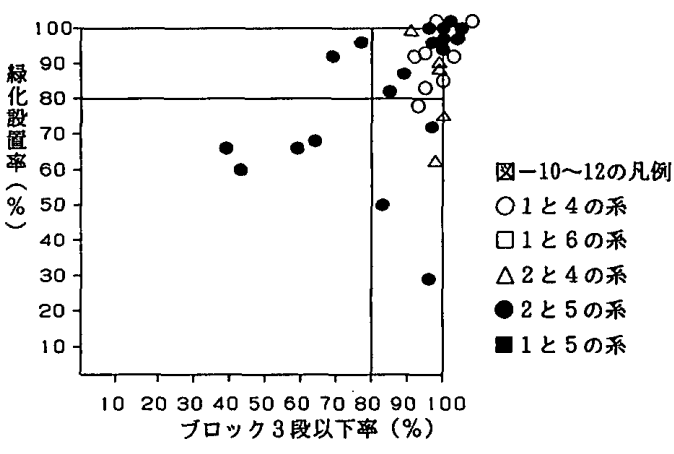

図一12垣：塀の構造の指定方法 〔両協定相違型〕の緑化状沉 
て、民間地場の $1.5 \mathrm{~m}$ 以上指定では、よい協定内容を指定 する割合が4/6区域（評価 A 以上 $4 / 6$ 区域）で $1.0 \mathrm{~m}$ 以下 の $3 / 16$ 区域（3/16区域）より極めて高く注目される。

\section{6-2 㪘地規模による接道部緑化効果}

調查各区域の平均敷地規模分布状況（210 ${ }^{2}$ 前後が最 も多い）より 3 区分しで評価の状況を表一 5 に示す。敷 地規模と評価の関係は、 $230 \mathrm{~m}^{2}$ 以上は $\mathrm{A}$ 以上 $11 / 22$ 区域 $(50 \%) 、 180 \sim 229 \mathrm{~m}^{2}$ は、32/41区域 $(78 \%) 、 179 \mathrm{~m}^{2}$ 以 下では、10/16区域（63\%）であり必ずしも相関してい ない。しかし、これを協定内容からみると、よい協定内 容ではどの規模でも評価 A 以上がほほ $100 \%$ であり、そ の他の内容の場合より著しく高く、敷地規模より協定内 容が強く影響しているといえる。

6-3 事業主体と接道部緑化効果

事業主体の内訳と緑化状況は、表一 5 の通り。事業主 体別に評価 A 以上をみると、民間大手 $32 / 34$ 区域（94\% ）、民間地場 $7 / 22$ 区域 $(35 \%)$ 、公共中央 $5 / 5$ 区域（ $100 \%$ ）、公共地場 9/18区域（55\%）であり民間大手と

\section{表一 5 各種条件における協定内容別緑化評価}

単位: 区城数，（）:\%

\begin{tabular}{|c|c|c|c|c|c|c|}
\hline & \multirow{3}{*}{ 項目内容 } & \multicolumn{4}{|c|}{ 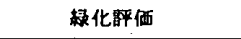 } & \multirow{3}{*}{ (合項目) } \\
\hline & & \multicolumn{2}{|c|}{$\begin{array}{l}\text { 上小 } \\
\text { 協定内容 }\end{array}$} & \multicolumn{2}{|c|}{ 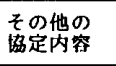 } & \\
\hline & & $A^{*} . A$ & $B \sim B$ & $A^{*} . A$ & $B \sim B$ & \\
\hline \multirow{6}{*}{ 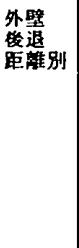 } & 铩指定 & 4 & 0 & 6 & 5 & $15(19)$ \\
\hline & $0.5 \mathrm{~m} \sim$ & 0 & 0 & 2 & 2 & $4(5)$ \\
\hline & $0.8 \mathrm{~m} \sim$ & 0 & 1 & 1 & 0 & $2(3)$ \\
\hline & 1. $0 \mathrm{~m} \sim$ & 8 & 2 & 13 & 1,4 & $37(47)$ \\
\hline & 1. $5 \mathrm{~m} \sim$ & 7 & 0 & 1 & 1 & $9\left(\begin{array}{ll}1 & 1\end{array}\right)$ \\
\hline & 2. $0 \mathrm{~m}$ 以上 & 8 & 0 & 3 & 1 & $12(15)$ \\
\hline \multirow{3}{*}{$\begin{array}{l}\text { 平坞 } \\
\text { 教地 } \\
\text { 面皘别 }\end{array}$} & $180 \mathrm{~m}^{2}$ 末满 & 4 & 1 & 6 & 5 & $16(20)$ \\
\hline & $180 \sim 230 \mathrm{~m}^{2}$ & 16 & 1 & 16 & 8 & $41(52)$ \\
\hline & $230 \mathrm{~m}^{2}$ 以上 & 7 & 1 & 4 & 10 & $22(28)$ \\
\hline \multirow{4}{*}{$\begin{array}{l}\text { 事菜 } \\
\text { 主体別 }\end{array}$} & 民間大手 & 17 & 1 & 15 & 1 & $34(43)$ \\
\hline & 民间地㙁 & 5 & 2 & 2 & 13 & $22(28)$ \\
\hline & 公共中央 & 2 & 0 & 3 & 0 & $5(6)$ \\
\hline & 公共地婸 & 3 & 0 & 6 & 9 & $18(23)$ \\
\hline \multirow{4}{*}{ 辢蛙 } & 両方一人㚳定 & 12 & 1 & 11 & 14 & $38(48)$ \\
\hline & 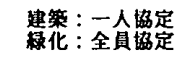 & 1 & 0 & 3 & 2 & $6(8)$ \\
\hline & 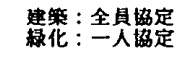 & 5 & 0 & 3 & 4 & $12(15)$ \\
\hline & 両方全貝協定 & 9 & 2 & 9 & 3 & $23(29)$ \\
\hline \multirow[t]{4}{*}{ 地形別 } & 平坦地 & 12 & 0 & 8 & 13 & $33(42)$ \\
\hline & 㮛傾斜 & 11 & 1 & 10 & 6 & $28(35)$ \\
\hline & 中傎斜 & 4 & 0 & 6 & 1 & $11(14)$ \\
\hline & 急傾斜 & 0 & 2 & 2 & 3 & $7(9)$ \\
\hline \multirow{3}{*}{$\begin{array}{l}\text { 区域 } \\
\text { 面䅡 }\end{array}$} & 3 ha未满 & 5 & 1 & 13 & 11 & $30(38)$ \\
\hline & $3 \sim 10$ ha & 17 & 2 & 8 & 9 & $36(46)$ \\
\hline & 10 ha以上 & 5. & 0 & 5 & 3 & $13(16)$ \\
\hline \multirow{2}{*}{$\begin{array}{l}\text { 器哥 } \\
\text { 年代別 }\end{array}$} & 1984 年以前 & 9 & 2 & 15 & 13 & $39(49)$ \\
\hline & 1985 手以後 & 18 & 1 & 11 & 10 & $40(51)$ \\
\hline 合 & 䂥 (各愐目) & 27 & 3 & 26 & 23 & $79\left(\begin{array}{lll}1 & 0 & 0\end{array}\right)$ \\
\hline
\end{tabular}

公共中央は著しく結果がよい。一方で、民間地場と公共 地場の結果が悪く特に民間地場が問題といえる。以下、 これを事業主体別に協定内容から検討する。なお、事業 主体の垣・塀設置への係わりに関しては、事業者（一部 ）へのヒヤリング調査 ${ }^{ \pm 22}$ を行なった。その結果、開発 時に区域全体を計画的に生垣を整備する（以下、計画的 整硔型とする）場合が多く見受けられた。これは、区域 の接道部緑化効果に基本的に影響することと考えられる ので、協定内容の検討の際合わせて考察を行う。

（1）、全区域を「計画的整備型」と業者や住民が個々に 整備するなどの「その他の整備型」に区分して、事業主 体別に緑化評価を表一6に示す。ただし、区分の確認が とれていない一部の区域では現地調査より判断したデー タによる。

表一6の結果より

（イ）計画的整備型は、31区域で全区域の約 4 割である が、事業者別では、民間大手の65\%（22区域）、民間地 場の $14 \%$ （3 区域）、公共地場の $22 \%$ （4 区域）が占め、

\section{表一6 垣・塀の整備方法と緑化評価（事業主体別）}

单位: 区域数

\begin{tabular}{|c|c|c|c|c|c|}
\hline \multirow{2}{*}{\multicolumn{2}{|c|}{ 整備方法 }} & \multicolumn{2}{|c|}{ よい協定内容 } & \multicolumn{2}{|c|}{ その他の㙝定内容 } \\
\hline & & $\mathrm{A}^{+}, \mathrm{A}$ & $B \sim E$ & $A^{+}, A$ & $B \sim E$ \\
\hline \multirow{5}{*}{$\begin{array}{l}\text { 計画的 } \\
\text { 整储型 }\end{array}$} & 民間大手 & 13 & 0 & 9 & 0 \\
\hline & 民間地軥 & 3 & 0 & 0 & 0 \\
\hline & 公共中央 & 0 & 0 & 2 & 0 \\
\hline & 公共地堨 & 1 & 0 & 3 & 0 \\
\hline & 計 & 17 & 0 & 14 & 0 \\
\hline \multirow{5}{*}{$\begin{array}{l}\text { その他の } \\
\text { 整備型 }\end{array}$} & 民間大手 & 4 & 1 & 6 & 1 \\
\hline & 民間地埸 & 2 & 2 & 2 & 13 \\
\hline & 公共中央 & 2 & 0 & 1 & 0 \\
\hline & 公共地場 & 2 & 0 & 3 & 9 \\
\hline & 計 & 10 & 3 & 12 & 23 \\
\hline
\end{tabular}

表一 7 両方共全員協定の事業主体別緑化評価 単位：区域数

\begin{tabular}{|c|c|c|c|c|c|}
\hline & \multicolumn{2}{|c|}{ よい協定内容 } & \multicolumn{2}{|c|}{ その他の協定内容 } \\
\hline & & $\mathrm{A}^{+}, \mathrm{A}$ & $B \sim E$ & $\mathrm{~A}^{+}, \mathrm{A}$ & $B \sim E$ \\
\hline \multirow{4}{*}{$\begin{array}{l}\text { 兩全 } \\
\text { 方貣 } \\
\text { 共協 } \\
\text { 定 }\end{array}$} & 民間大手 & 3 & 0 & 8 & 0 \\
\hline & 民間地場 & $5(0)$ & $2(0)$ & $0(2)$ & $3(8)$ \\
\hline & 公共地場 & 1 & 0 & 1 & 0 \\
\hline & 合 & 9 & 2 & 9 & 3 \\
\hline
\end{tabular}

（）内は民間地場の网方一人協定の区域数内訳（10区域）

\section{表一8 区域面積の事業主体別緑化評価}

単位: 区域数，（）：\%

\begin{tabular}{|c|c|c|c|c|c|}
\hline \multirow{2}{*}{ 区域 } & \multicolumn{2}{|c|}{ 上い㚳定内容 } & \multicolumn{2}{|c|}{ そ0他の别定内容 } & \multirow{2}{*}{ 合 竍 } \\
\hline & $\mathrm{A}^{+} \cdot \mathrm{A}$ & $B \sim E$ & $\mathrm{~A}^{+}, \mathrm{A}$ & $B \sim E$ & \\
\hline 3ha末满 & $4 / 1$ & $1 / 0$ & $6 / 2$ & $0 / 7$ & $11(32) / 10(45)$ \\
\hline $3 \sim 10 \mathrm{ha}$ & $10 / 4$ & $0 / 2$ & $5 / 0$ & $0 / 6$ & $15(44) / 12(55)$ \\
\hline 10ha以上 & $3 / 0$ & $0 / 0$ & $4 / 0$ & $1 / 0$ & $8(24) / 0$ \\
\hline 合計 & $17 / 5$ & $1 / 2$ & $15 / 2$ & $1 / 13$ & $34(100) / 22(100)$ \\
\hline
\end{tabular}

（注）民間大手/民間地埸 
民間大手で最も行なわれているタイプといえる。

（口）計画的整倩型は、協定内容に関係なく全て評価 $\mathrm{A}$ 以上であるが、よい協定内容を指定する割合は、17/31 区域 $(55 \%)$ とそれ程高くない。今後の緑化保全のため には、その割合を高める必要があると考えられる

（八）その他の整備型は、評価 A以上の割合は、よい協 定内容では10/13区域（77\%）、その他の協定内容では $12 / 35 区$ 域 $(35 \%)$ で、よい協定内容の影響がうかがわ れる。しかし、よい協定内容を指定する割合が13/48区 域 (27\%) と極めて低い。さらに、その他の整備型で、 かつ、その他の協定内容にする区域は全区域の $44 \%(35$ /79区域）とかなり多いことが問題点である。

（2）民間大手の場合、よい協定内容とその他の協定内 容は半々の割合であり、評価は共に極めて高く差がない。 従って、効果は協定内容以外の要因もあると考えられる。 民間大手は表一 6 の通り、計画的整備型が 7 割近くあり 最も大きな要因であると考えられる。また、その他の整 借型で、かつ、その他の協定内容でも効果が高いのは協 定への意識も高いと思われる（事業者ヒヤリング）。

（3）公共中央は、事例が少ないが、民間大手と同様の 傾向にあり、これは民間大手への外注による計画的整備 型や協定への意識の高さに起因していると考えられる（ 事業者ヒヤリング）。

（4）民間地場は、評価 A 以上の㓶合はよい協定内容で

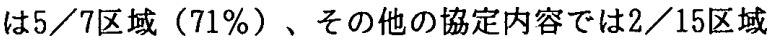

(13\%) であり、よい協定内容の影響が強くうかがわれ る。しかし、民間地場では、よい㙝定内容を指定する割 合は7/22区域 $(32 \%)$ であり、その他の整備型では $4 /$ $19(21 \%)$ とさらに低い。また、民間地場では計画的整 備型にする割合が14\%と極めて少なく、さらに、その他 の整備型で、かつ、その他の協定内容とするケースが 15 /22区域（68\%）とかなり多い。従って、よい協定内容 にする割合を高めることが最も必要である。

（5）公共地場は、評価 $\mathrm{A}$ 以上の割合はよい協定内容で は3/3区域 (100\%)、その他の協定内容では6/15区域 (40\%) であり、よい協定内容の影響がうかがわれる。 公共地場の場合、よい協定内容を指定する割合が $3 / 18$ 区 域 $(17 \%)$ であり、その他の整備型では $2 / 14$ 区域（14 \%) とさらに低い。また、計画的整硔型にする割合は 4 $/ 18$ 区域 $(22 \%)$ と低く、さらに、その他の整備型で、 かつ、その他の協定内容とするケースが12／18区域（67 \%) とかなり高い。従って、よい協定内容にする割合を 高めることが最も必要である。

なお、前橋市の地域条件（後述）による 7 区域を例外 的事例としても、よい協定内容の割合は $3 / 11$ 区域 $(27 \%$ ）と低い。

ただし、公共地場の場合、事業者ヒヤリングでは、民 間大手への外注による効果と考えられるケースが見受け
られ（表-6の計画的整備型 4 事例）、対応によって、 よい結果が期待できる可能性がうかがわれる。

\section{6-4 締結要件と接道部緑化効果}

各協定共、いわゆる一人協定と全員協定による締結方 法があり、その内訳を表一 5 の通りに示す。これを協定 内容からみると、よい協定内容では、どの締結方法でも $100 \%$ 評価 A 以上がほとんどで、その他の内容の場合と 比べてかなり高く、効果への影響の強さがうかがわれる。 ただし、両方共全員協定の割合は、よい協定内容とそ 他の協定内容とも評洒 A 以上の割合は高率で差がなく、 協定内容以外の要因も考えられる。そこで、両方全員協 定の場合の協定内容別評価を事業主体別に示すと表一 7 の通りとなる。これより、その他の協定内容の評価 A 以 上の 9 区域は民間大手 8 区域、公共地場 1 区域であり、 協定への意識の高さや計画的整備型区域の影響によると 考えられる。

なお、表一 7 より、民間地場の場合は、よい協定内容 を指定する割合が両方共一人協定 0/10区域と皆無であ るのに対して、両方共全員協定は7／10区域と極めて高く かつ評価もよい傾向にあり注目される。

6-5 住宅地の地形と接道部緑化効果

住宅地の地形は、平坦地から急傾斜地までの 4 分類と したが、平坦地以外の基準は区域の平均的傾斜度に基ず く画地間の高低差が $1 \mathrm{~m}$ 以内を緩傾斜、1 $2 \mathrm{~m}$ を中傾 斜、 $2 \mathrm{~m}$ 以上を急傾斜とした。地形別評価を表一 5 に示 す。協定内容からみると、平坦地、緩傾斜、中傾斜では 、よい協定内容ではほほ評価 A 以上であり、その他の内 容に比べてその影響の強さがうかがわれる。また、よい 協定内容を指定する割合はほとんど差がなく地形による 影響はないと考えられる。ただし、中傾斜地では、その 他の協定内容で評価 A 以上の割合が極めて高いのは、民 間大手と公共地場における計画的整備型区域が多いこと に起因している。急傾斜地では、事例は少ないが生垣と フェンスの併用を含めて 7 事例全てにフェンスを指定し ており、よい協定内容になりにくいのは安全性に起因す るものと思われる。

いずれの協定内容とも評価がよくなく、6例に緑化率の 低下がみられるのは、眺望, プライバシーの不要などが 影響しているものと推察される。

\section{6-6 協定区域面積と接道部緑化効果}

調査区域の区域面積（建築協定区域）の分布状況によ り 3 区分して協定内容別緑化状況を表一 5 に示す。これ より、評価 $\mathrm{A}$ 以上の区域は、3 ha未満60\%、3～10ha70 $\% 、 10 \mathrm{ha}$ 以上 $77 \%$ で、3 ha未満が比較的よくない。協定 内容でみると、よい協定内容ではどの規模でもほほ評価 A以上であるが、その他の協定内容ではかなり少なく、 その影響がうかがわれる。3 ha未満の小規模開発では、 よい協定内容を指定する割合が $6 / 30$ 区域 $(20 \%)$ と他 
に比べてかなり低いのが目立ち、効果の低さの要因と考 えられる。この点に関して、事業主体（民間大手と民間 地場）との関係を表一8に示す。民間地場は、 3 ha未満 の割合が10/22区域（45\%）で民間大手の11/34区域（ $32 \%$ ）上り多い。そして、3 ha未満の民間地場の場合は、 よい協定内容を指定する割合が $1 / 10$ 区域である。これ は、3 ha未満の民間大手 $5 / 11$ 区域や、民間地場 $3 \sim 10$ haの $6 / 12$ 区域よりかなり低い。よい協定内容の指定は、 民間地場の場合評価 $\mathrm{A}$ 以上 $5 / 7 区$ 域 $($ 表一 -8$) \cdot$ と、評価 をょくする可能性がある。従って特に、民間地場の小規 模区域には行政指導が必要と考えられる。

6-7 認可年と接道部緑化効果

認可年を最近10年間とそれ以前とした区分でみた場合 の緑化状況を表一 5 に示す。耐区分共、評価 A 以上はよ い協定内容では多いが、その他の協定内容では少ない。 しかし、よい協定内容の割合を比較すると、最近10年間 の $48 \%$ が、それ以前の $28 \%$ をかなり上回っており、協定 内容の改善が明らかである。

なお、調査結果における認可年から調査時までの経年変 化については、 5 年間の・ケーススタディらと、住民の対 応に関するアンケート調査 ${ }^{6 を}$ を行い检討した。その結果 では、協定内容による相違はあるが、一般に緑化率、ブ ロック 3 段以下率ともに、90\%以上の場合やや低下また は変化なし、90\%末満の場合は上昇する傾向が見られた。 従って、本論における評価において、A以上評価は変更 ないと考えられるが、B〜E評価において認可年が新し. い区域は若干の区域で下位に評価されている可能性があ゙ ると推察される。

$6-8$ 地域性と接道部緑化効果

地域性を検討するため、調査区域の自治体ごとに協定 内容別緑化状況を表一 1 に示した。各自治体共、よい協 定内容ではほぼ評価 A 以上であるが、その他の内容では その割合がかなり低く、協定内容による効果への影響は 全国的傾向といえる。しかし、次の 3 自治体については、 協定内容や緑化状況が地域的条件によると考えられる。 前橋市と宇治市に評価の悪さが、目立つ。前橋は、地域独 特のからっ風防止の為、北側の高いブロック（8 段位） を指定内容で認めているので 3 段以下率が低く、それが 緑化率の低下にもつながっている。宇治は、敷地が非常 に狭くかつ間口も狭いため緑化率が低く、また、地域の 風習と思われる種々のデザインによる垪への指向に起因 して、協定内容でもかなり高い拼（1.8m、2.0m以下）を認 めていることが、非常に低い3 段以下率につながってい る。次に千葉市は、地域性によるとは考えられないが（ 自治体ヒヤリング)、緑化協定においては垣・塀の構造 がほとんど無指定であり、中高木指定に重点をおいた独 自の方法である。

なお、事業主体については表一1の（）内に評価 $\mathrm{A}$
以上の区域数を示した。民間大手の開発は全国的に分布 し、ほとんど評価 A 以上である。民間地場は全国的に評 価が低い傾向にあり、公共地場は高い場合と低い場合が あり一定していない。以上より、事業主体による協定内 容と評価の傾向は一般に地域差はないと考えられる。

7.まとめ

（1）緑化協定および建築協定を二重に締結した区域は、 戸建住宅地を主体に1980年代より增加し、現在では全国 的にかなりの締結状況にある。

（2）二重協定は、戸建住宅地の接道部緑化に極めて有 効な施策である。

（3）二重協定の接道部緑化効果に最も影響を及ほすすの は、協定書中の垣・塀の指定内容である。

（4）両協定による垣・塀の指定内容の一般的傾向とし て、効果が最も大きいのは〔生垣のみ、又はそれにC . Bの禁止（3 段以下）を付加した組合せ了であり、次い で〔生垣と無指定の組合せ〕もかなり効果がある。一方、 どちらかの協定で、〔生垣又はフェンス〕として生垣に 限定しない場合は、効果がかなり劣り、さらに $[\mathrm{C} \cdot \mathrm{B}$ も可」とした場合は、最も効果が劣る。

（5）両協定による指定の方法と内容で最も効果がある のは、（イ）【生垣〕又は〔生垣十C・Bの禁止〕を両 協定一致して指定する方法、並びに（口）緑化協定で、 生垣〕、建桑協定で、〔生垣+C・Bの禁止〕または〔C ：Bの禁止了を両協定相違で指定する方法である。次い で（八）緑化協定で〔生垣〕、建築協定で〔無指定〕と する緑化協定単独の方法もかなり効果がある。

（6）緑化協定で〔生垣〕を指定すると、緑化での指定 が影響して上記（イ）～（ハ）の型になりやすい傾向が あるので、緑化担当課による主導的役割が要請される。

さらに、よい協定内容にするには協定締結に当って指 導的立場にある両協定行政担当者の協議が必要であるが、 アンケート調相 ${ }^{\circledR 3)}$ では、比較的少ない現状であり努力 が望まれる(表一9)。

\section{表-9 自治体の協定内容の協議事項}

複数回答, 回答自治体数 $41(100 \%)$

\begin{tabular}{|c|c|c|c|}
\hline \multirow{4}{*}{$\begin{array}{r}\text { する } \\
17 \\
\text { 自 } \\
\text { 治 } \\
\text { 体 } \\
\text { (42) }\end{array}$} & \multirow{4}{*}{$\begin{array}{l}\text { 協 } \\
\text { 議 } \\
\text { 事 } \\
\text { 項 }\end{array}$} & 道路側外壁後退距離 & $7(17)$ \\
\hline & & 建ぺい率 & $8(20)$ \\
\hline & & 道路側垣・塀の構造 & $13(32)$ \\
\hline & & 有効期間 & $10(24)$ \\
\hline \multicolumn{4}{|c|}{ 24自治体（58） } \\
\hline
\end{tabular}


（7）民間大手の事業者は、よい協定内容でない場合で も計画的整借型が大半で著しく緑化効果の高い開発を行 っており、また、公共中央や公共地場の開発にも参入し て影響を及ほしている。しかし、今後の緑化効果維持の ためには、よい協定内容の指定が必要と考えられる。

（8）民間地場の事業者の開発は、一般に、協定内容が 悪く、小規模な区域も多い。計画的整備型も少なく極め て結果がよくない。そこで、以下の点についての行政指 導と事業者努力が望まれる。

（イ）よい協定内容にすること。特に小規模開発での行 政指導が必要である。（口）道路側外壁後退距離を $1.5 \mathrm{~m}$ 以上にすること。（ハ）両方共全員協定にして、十分な 説明を通じ住民の協力を得ること。（二）緑化計画書の 充実と生垣の分諼時の整備。（ホ）工事中における協定 内容のチェック。

なお、行政側による工事中のチェックの現状は、アン

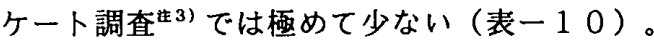

（9）公共地場の開発の場合、評価が一定しない傾向が あるが、以下の対応を行うことで、評価の向上が期待で きる。（イ）よい協定内容にすること。（口）民間大手 への外注による計画的整備型の道入を計る。

終りに、次報では二重協定に関して(1)締結の条件や契 機(2)緑化・建築各単独協定との効果や協定内容などの比 較(3)普及方法の娭討、などを予定している。

表一10 自治体による

垣・塀の工事中のチェックの有無

回答自治体 $35(100 \%)$

\begin{tabular}{|l|l|}
\hline 両課ともする (同一担当課含む) & $4(11)$ \\
\hline 建築協定担当課がする & $4(11)$ \\
\hline 緑化協定担当課がする & $1(3)$ \\
\hline 両課ともしない & $26(75)$ \\
\hline
\end{tabular}

参考文献

参 1) 山口 紘, 坂本磐雄, 田中正美, 前田修「緑化 協定および建築協定両制度締結による戸建住宅地 の接道部緑化に関する研究」日本建築学会九州支 部研究報告 第32号

P P. 181 184，1991年 3 月

2 ）坂本磐雄, 山口 紘, 田中正美, 前田 修「緑化 協定制度による戸建住宅地生垣化効果に関する研 究」日本都市計画学会論文集 No. 24,

P P. 241 246，1990年11月

3) 田中正美, 坂本磐雄, 山口 紘, 前田修「建筑 協定制度による戸建住宅地接道部緑化の可能性に 関する研究」日本都市計画学会論文集 No. 27, P P. 121 126，1992年11月

4) 坂本磐雄, 山口 紘, 田中正美, 前田修「戸建 住宅地緑化・建築協定区域における接道部緑化状 況の経年変化」日本建築学会大会学衍講演梗概集, P P. 309 310，1993年 9 月

5 ) 田中正美, 坂本整雄, 山口 紘, 前田修「戸建 住宅地における接道部緑化状況の経年変化、その 1 〜 その 2 」日本建築学会大会学術講演梗概集, P P. 735 738，1994年 9 月

6 ）山口紘, 坂本整雄, 田中正美, 前田修「緑化 協定および建筑協定両制度楴結区域住民に対する 戸建住宅地の生垣化に関するアンケート調查報告 No. $2 」$ 日本建築学会中国 - 九州支部研究報告 第 4 号 P P. 205 208，1993年 3 月

注釈

1 ）建設省都市局公園緑地課「緑化協定締結状況調書 （1990年 3 月 31 日現在）」と、建設省住宅局市街地 建築課「建築協定認可一覧（1990年 3 月末現在）」 を基本にして、ぎょうせい出版・建築法令例規 7 統 計資料「建築協定一覧」および、当研究グループに よる自治体アンケート（1988年11月，1991年10月， 1993年 2 月）と調查時の資料により補完した。

2 ）福岡市, 新宮町, 遠賀町, 佐世保市, 熊本市, 広島 市, 福山市, 宇治市, 浜松市, 小川町, 鳩山町, 所 沢市，いわき市，秋田市における該当 32 二重協定区 域について民間大手 13 ，民間地場 4, 公共中央 2 ， 公共地場 3 の合計 22 事業主体へのヒヤリング調查に よる。また、民間大手 5 ，公共中央 3 各事業体（本 社）への二重協定に関するヒヤリング調查からも知 見を得た。

3) 1993年 8 月に当研究グループで実施した該当自治体 への「緑化協定および建築協定両制度締結に関する アンケート調查」による。送付56自治体 回答45自 治体（回答率 $80 \%$ ） 